\title{
Nitro-Oleic Acid in Seeds and Differently Developed Seedlings of Brassica napus L.
}

\author{
Martin Vollár ${ }^{1}$, Gábor Feigl ${ }^{2}$ (), Dóra Oláh ${ }^{2}$, Attila Horváth ${ }^{1}$, Árpád Molnár ${ }^{2}$, Norbert Kúsz ${ }^{1}$, \\ Attila Ördög ${ }^{2}$, Dezső Csupor ${ }^{1}$ (i) and Zsuzsanna Kolbert ${ }^{2, *}$ (B) \\ 1 Institute of Pharmacognosy, Faculty of Pharmacy, University of Szeged, H-6701 Szeged, Hungary; \\ vollar@pharmacognosy.hu (M.V.); horvath.attila@pharmacognosy.hu (A.H.); \\ k.norbi@pharmacognosy.hu (N.K.); csupor.dezso@pharmacognosy.hu (D.C.) \\ 2 Department of Plant Biology, Faculty of Science and Informatics, University of Szeged, H-6726 Szeged, Hungary; \\ feigl@bio.u-szeged.hu (G.F.); olah.dora18@citromail.hu (D.O.); molnara@bio.u-szeged.hu (A.M.); \\ aordog@bio.u-szeged.hu (A.Ö.) \\ * Correspondence: kolzsu@bio.u-szeged.hu
}

Received: 5 February 2020; Accepted: 23 March 2020; Published: 24 March 2020

check for updates

\begin{abstract}
Similar to animals, it has recently been proven that nitro-fatty acids such as nitro-linolenic acid and nitro-oleic acid ( $\left.\mathrm{NO}_{2}-\mathrm{OA}\right)$ have relevant physiological roles as signalling molecules also in plants. Although $\mathrm{NO}_{2}-\mathrm{OA}$ is of great therapeutic importance, its presence in plants as a free fatty acid has not been observed so far. Since Brassica napus (oilseed rape) is a crop with high oleic acid content, the abundance of $\mathrm{NO}_{2}-\mathrm{OA}$ in its tissues can be assumed. Therefore, we quantified $\mathrm{NO}_{2}-\mathrm{OA}$ in $B$. napus seeds and differently developed seedlings. In all samples, $\mathrm{NO}_{2}-\mathrm{OA}$ was detectable at nanomolar concentrations. The seeds showed the highest $\mathrm{NO}_{2}-\mathrm{OA}$ content, which decreased during germination. In contrast, nitric oxide $(\bullet \mathrm{NO})$ levels increased in the early stages of germination and seedling growth. Exogenous $\mathrm{NO}_{2}-\mathrm{OA}$ treatment $(100 \mu \mathrm{M}, 24 \mathrm{~h})$ of Brassica seeds resulted in significantly increased $\bullet \mathrm{NO}$ level and induced germination capacity compared to untreated seeds. The results of in vitro approaches (4-Amino-5-methylamino-2', $7^{\prime}$-difluorofluorescein (DAF-FM) fluorescence, -NO-sensitive electrode) supported the $\bullet \mathrm{NO}$ liberating capacity of $\mathrm{NO}_{2}-\mathrm{OA}$. We observed for the first time that Brassica seeds and seedlings contain free $\mathrm{NO}_{2}-\mathrm{OA}$ which may be involved in germination as an $\bullet \mathrm{NO}$ donor as suggested both by the results of exogenous $\mathrm{NO}_{2}-\mathrm{OA}$ treatment of seeds and in vitro approaches. Due to their high $\mathrm{NO}_{2}-\mathrm{OA}$ content, Brassica sprouts can be considered as a good source of dietary $\mathrm{NO}_{2}-\mathrm{OA}$ intake.
\end{abstract}

Keywords: Brassica napus; germination; nitro-oleic acid; nitric oxide; seedlings; seeds

\section{Introduction}

Nitro-fatty acids ( $\mathrm{NO}_{2}$-FA) as endogenous signal molecules in animals and humans have gained great attention, since these nitrated lipid derivatives exert relevant bioactivity in association with anti-thrombotic, cytoprotective, and anti-inflammatory processes (recently reviewed in Ref. [1]). The addition reaction of nitric oxide $(\bullet N O)$ and $\bullet$ NO-derived higher oxides of nitrogen (peroxynitrite, nitrogen dioxide) with conjugated double bond-containing, unsaturated fatty acids results in the formation of $\mathrm{NO}_{2}-\mathrm{FA}$; although, the in vivo mechanism is still unknown [2]. During the first proposed mechanism, radical hydrogen abstraction from a bis-allylic carbon takes place resulting in the formation of an alkyl radical which is followed by the formation of a peroxyl radical via double bond rearrangement and molecular oxygen insertion. The insertion of nitrogen dioxide $\left(\bullet \mathrm{NO}_{2}\right)$ and the consequent formation of a non-electrophilic nitroalkane-alkene product is also possible [3]. The second mechanism includes 
the formation of a carbon-centred radical as the result of the direct addition of $\bullet \mathrm{NO}_{2}$. This can be followed by further oxidation steps yielding the electrophilic nitro-alkene [4].

Although the occurrence and bioactivity of nitrated fatty acids is well-characterized in animals, these interesting molecules have recently been the focus of attention in plants. The presence of endogenous $\mathrm{NO}_{2}$-FAs such as nitro-conjugated linoleic acid $\left(\mathrm{NO}_{2}\right.$-cLA) and nitro-oleic acid-cysteine $\left(\mathrm{NO}_{2}\right.$-OA-Cys) adducts have been detected in extra-virgin olive oil (EVOO) and fresh olives [5]. By incubating EVOO with nitrating agents, Fazzari et al. [4] was able to detect nitro-linolenic acid $\left(\mathrm{NO}_{2}-\mathrm{Ln}\right)$ and nitro-linoleic acid ( $\mathrm{NO}_{2}$-LA). Later, in Arabidopsis thaliana at different developmental stages [6], in pea roots and leaves as well as in rice leaves, $\mathrm{NO}_{2}$ - $\mathrm{Ln}$ proved to be the major endogenous $\mathrm{NO}_{2}-\mathrm{FA}$ [7]. Recently, Di Palma et al. [8,9] quantified $\mathrm{NO}_{2}-\mathrm{OA}$ in tomato cell suspensions treated with exogenous $\mathrm{NO}_{2}$-OA supporting the internalization of this nitrated derivative in tomato cells.

Nitro-fatty acids show electrophilic reactivity towards cellular nucleophilic targets such as reduced glutathione or protein cysteine (Cys) and histidine (His) residues. This results in the reversible formation of protein- $\mathrm{NO}_{2}-\mathrm{FA}$ adducts, which serve as a reservoir and also control the size of the free $\mathrm{NO}_{2}-\mathrm{FA}$ pool. The fast adduction of $\mathrm{NO}_{2}-\mathrm{OA}$ to thiol containing proteins and to glutathione has been revealed in mice plasma [10], while recently $\mathrm{NO}_{2}$-OA-glutathione adducts have been identified in tomato cell suspension [8].

At the same time, the electrophilic reactivity causes post-translational modifications of Cys and His containing proteins affecting their distribution and/or function [11]. These nitroalkylation reactions are partly responsible for the biological role of $\mathrm{NO}_{2}-\mathrm{FA}$ [12]. Additionally, $\mathrm{NO}_{2}-\mathrm{FA}$ have been reported to release $\bullet \mathrm{NO}$ in aqueous environments thus acting as endogenous $\bullet \mathrm{NO}$ donors and transducing the $\bullet \mathrm{NO}$ signal [13-16]. The signalling role of $\mathrm{NO}_{2}$-FA (especially $\mathrm{NO}_{2}$ - $\mathrm{Ln}$ ) was further supported by the fact that $\mathrm{NO}_{2}$-Ln content was modified during plant development and by abiotic stress [6]. Moreover, transcriptomic analysis revealed several genes, the expression of which was positively or negatively modulated by $\mathrm{NO}_{2}$ - $\mathrm{Ln}$, indicating the signalling role of $\mathrm{NO}_{2}$ - $\mathrm{Ln}$ in plant cells [6]. Recently, the signalling role of $\mathrm{NO}_{2}$-OA has also been revealed since it induces the production of reactive oxygen species possibly through the reduction of glutathione pool or via the activation of NADPH oxidase and triggers plant defence responses in tomato cells $[8,9]$.

Due to its role in animal signal transduction [17-19] $\mathrm{NO}_{2}-\mathrm{OA}$ is the most intensively studied $\mathrm{NO}_{2}$-FA with potent anti-inflammatory effects [20]. Studies in animal models pointed out the protective role of $\mathrm{NO}_{2}-\mathrm{OA}$ in cardiovascular, renal, and metabolic diseases [10,21,22], therefore its therapeutic application is promising. Identifying plant-derived dietary sources of $\mathrm{NO}_{2}$-FAs, specially the well-studied $\mathrm{NO}_{2}$-OA and its beneficial effects, would constitute a suitable way to access to the valuable properties described for these relevant molecules.

Brassica sprouts are rich sources of nutrients, phytochemicals, vitamins, minerals, enzymes, amino acids, and fatty acids, therefore they have high nutritional value [23]. The most abundant fatty acids in Brassica sprouts are oleic, linoleic, linolenic, erucic, palmitic, and stearic acids which account for 89-94\% of the total fatty acid content [24]. Brassica napus (oilseed rape) seedlings are especially rich in oleic acid (61\% of the total fatty acids, [24]), but the endogenous presence of $\mathrm{NO}_{2}-\mathrm{OA}$ in this species as well as in other plants has not been observed so far. Therefore, our aim was to examine the presence of $\mathrm{NO}_{2}$-OA in differentially developed Brassica plants. Furthermore, we aimed to examine the putative biological functions of $\mathrm{NO}_{2}-\mathrm{OA}$ in Brassica seeds and seedlings.

\section{Results and Discussion}

\subsection{Characterization of the Synthesized $\mathrm{NO}_{2}-\mathrm{OA}$ Standard}

The synthesized compound was identified as (E)-9-nitrooctadec-9-enoic acid based on the identical ${ }^{1} \mathrm{H}$ and ${ }^{13} \mathrm{C}$ NMR data with those reported in the literature [25]. This was assured by mass spectrometric measurements where the measured molecule ion mass was shown to be $m / z 326.5$, calculated neutral molecule mass was $327.4589 \mathrm{Da}$, molecular formula $\mathrm{C}_{18} \mathrm{H}_{33} \mathrm{NO}_{4}$ (Figure 1A,B). 

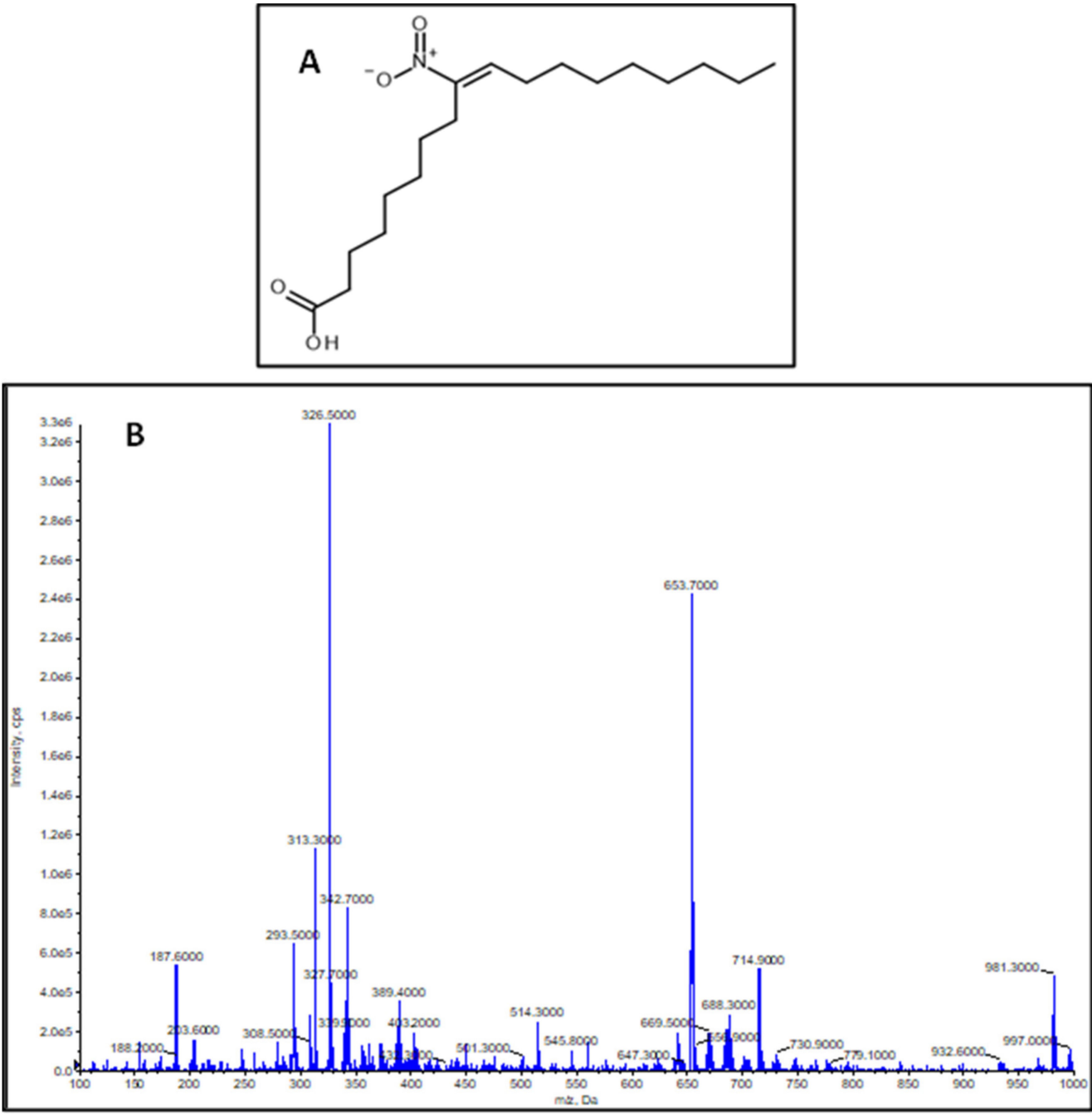

Figure 1. (A) Structure of (E)-9-nitrooctadec-9-enoic acid. (B) Q1 MS scan of nitro-oleic acid ( $\left.\mathrm{NO}_{2}-\mathrm{OA}\right)$ standard. Scan range was set between $m / z 100$ and $1000 \mathrm{Da}$. Molecule ion peak $[\mathrm{M}-\mathrm{H}]^{-}$was $m / z$ 326.5.

\subsection{Calibration}

From the synthesized standard a stock standard was prepared with methanol (HPLC grade) and working solutions were prepared $(50-2500 \mathrm{ng} / \mathrm{mL})$ by diluting the stock standard. Each solution was injected three times, the precision (Relative Standard Deviation, RSD, \%) of the calibration measurements ranged between 1.2093-2.3633\%. Calibration showed linear regression, the $\mathrm{R}^{2}$ value was 0.9986 , the limit of detection (LOD, $\mathrm{S} / \mathrm{N}=3.3$ ) was $0.1184 \mathrm{nmol} / \mathrm{mL}$, and the limit of quantitation (LOD, $\mathrm{S} / \mathrm{N}=10$ ) was $0.3588 \mathrm{nmol} / \mathrm{mL}$ (Figure 2).

\section{3. $\mathrm{NO}_{2}-\mathrm{OA}$ Content of Brassica napus at the Seed and Seedling Stages}

Seeds and seedlings of Brassica napus are remarkably rich in the unsaturated fatty acid, oleic acid, which implies the possibility of the presence of $\mathrm{NO}_{2}-\mathrm{OA}$ in Brassica as well. Figure 3A represents Brassica napus seeds and seedlings at day 0 , and 2nd, 4th, and 7th day after sowing. Therefore, we performed the analyses of $\mathrm{NO}_{2}-\mathrm{OA}$ concentrations and the quantitative data are presented in Table 1, while the mean $\mathrm{NO}_{2}-\mathrm{OA}$ concentrations with standard errors are shown in Figure 3. Ion chromatograms of the reference standard $\mathrm{NO}_{2}-\mathrm{OA}$ and of the 7-day-old Brassica napus seedlings are presented in Figure 4. Further chromatograms are presented as Figure S1. In samples, one further unidentified isomer of $\mathrm{NO}_{2}-\mathrm{OA}$ can be detected with higher retention time. 


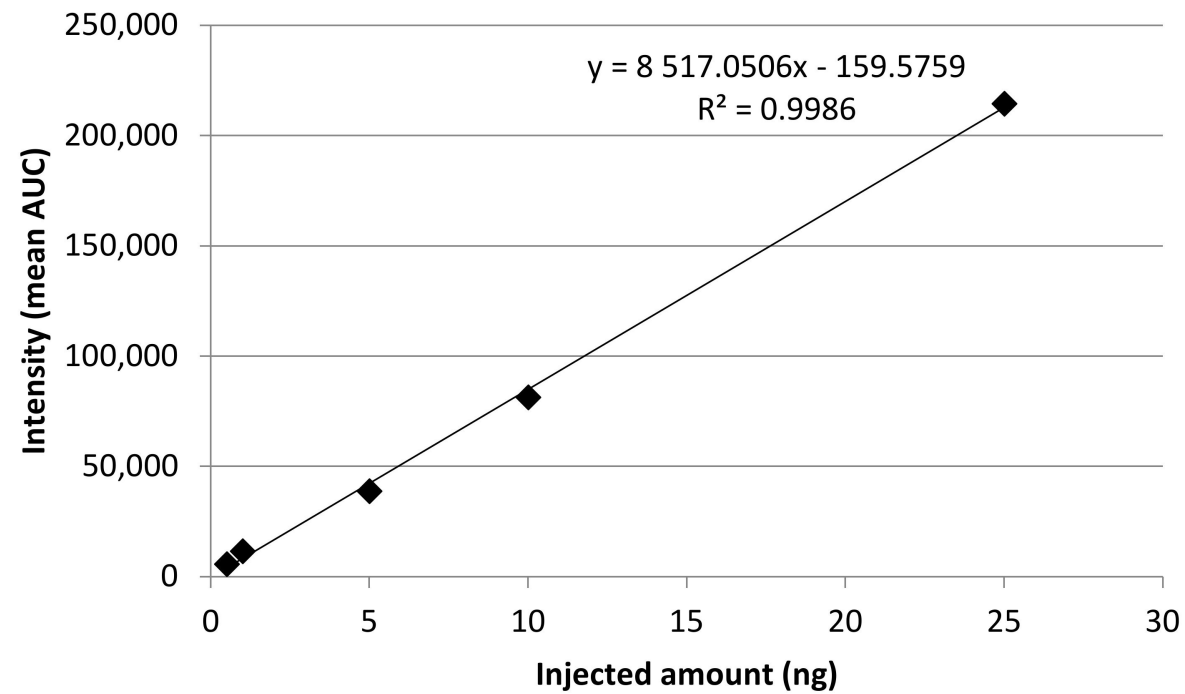

Figure 2. Calibration line of $\mathrm{NO}_{2}-\mathrm{OA}$ standard. Axis $\mathrm{X}$ shows the range of injected $\mathrm{NO}_{2}-\mathrm{OA}$ amount (ng) from working solutions, axis Y shows the mean area under curve (AUC) of the working solutions.

Table 1. Concentrations of nitro-oleic acid $\left(\mathrm{NO}_{2}-\mathrm{OA}\right)$ in B. napus seeds and differently developed seedlings. N/A (not available) indicates data under the detection limit. Samples were injected three times, the precision (RSD, \%) of the sample measurements ranged between $0.1348-3.9822$ RSD\%. The precision between the parallel samples ranged between $9.4828-26.6930$ RSD $\%$.

\begin{tabular}{|c|c|c|c|}
\hline Sample & $\begin{array}{l}\mathrm{NO}_{2} \text {-OA Concentration } \\
\text { (nmol/g Fresh Weight) }\end{array}$ & $\begin{array}{c}\text { Mean } \mathrm{NO}_{2}-\mathrm{OA} \\
\text { Concentration (nmol/g } \\
\text { Fresh Weight) }\end{array}$ & RSD (\%) \\
\hline Seed 1 & 1.4582 & \multirow{3}{*}{1.6987} & \multirow{3}{*}{12.2753} \\
\hline Seed 2 & 1.8293 & & \\
\hline Seed 3 & 1.8086 & & \\
\hline Seedling 2 nd day 1 & 0.4378 & \multirow{3}{*}{0.3701} & \multirow{3}{*}{16.1281} \\
\hline Seedling 2nd day 2 & 0.3475 & & \\
\hline Seedling 2 nd day 3 & 0.3250 & & \\
\hline Seedling 4 th day 1 & \multirow{3}{*}{\multicolumn{3}{|c|}{ N/A }} \\
\hline Seedling 4 th day 2 & & & \\
\hline Seedling 4 th day 3 & & & \\
\hline Seedling 7 th day 1 & 0.5569 & \multirow{3}{*}{0.6622} & \multirow{3}{*}{26.6930} \\
\hline Seedling 7 th day 2 & 0.8663 & & \\
\hline Seedling 7 th day 3 & 0.5635 & & \\
\hline Shoot 7th day 1 & 0.3124 & \multirow{3}{*}{0.3470} & \multirow{3}{*}{12.2250} \\
\hline Shoot 7th day 2 & 0.3943 & & \\
\hline Shoot 7th day 3 & 0.3343 & & \\
\hline Root 7th day 1 & 0.4681 & \multirow{3}{*}{0.4260} & \multirow{3}{*}{9.4828} \\
\hline Root 7th day 2 & 0.3876 & & \\
\hline Root 7 th day 3 & 0.4221 & & \\
\hline
\end{tabular}



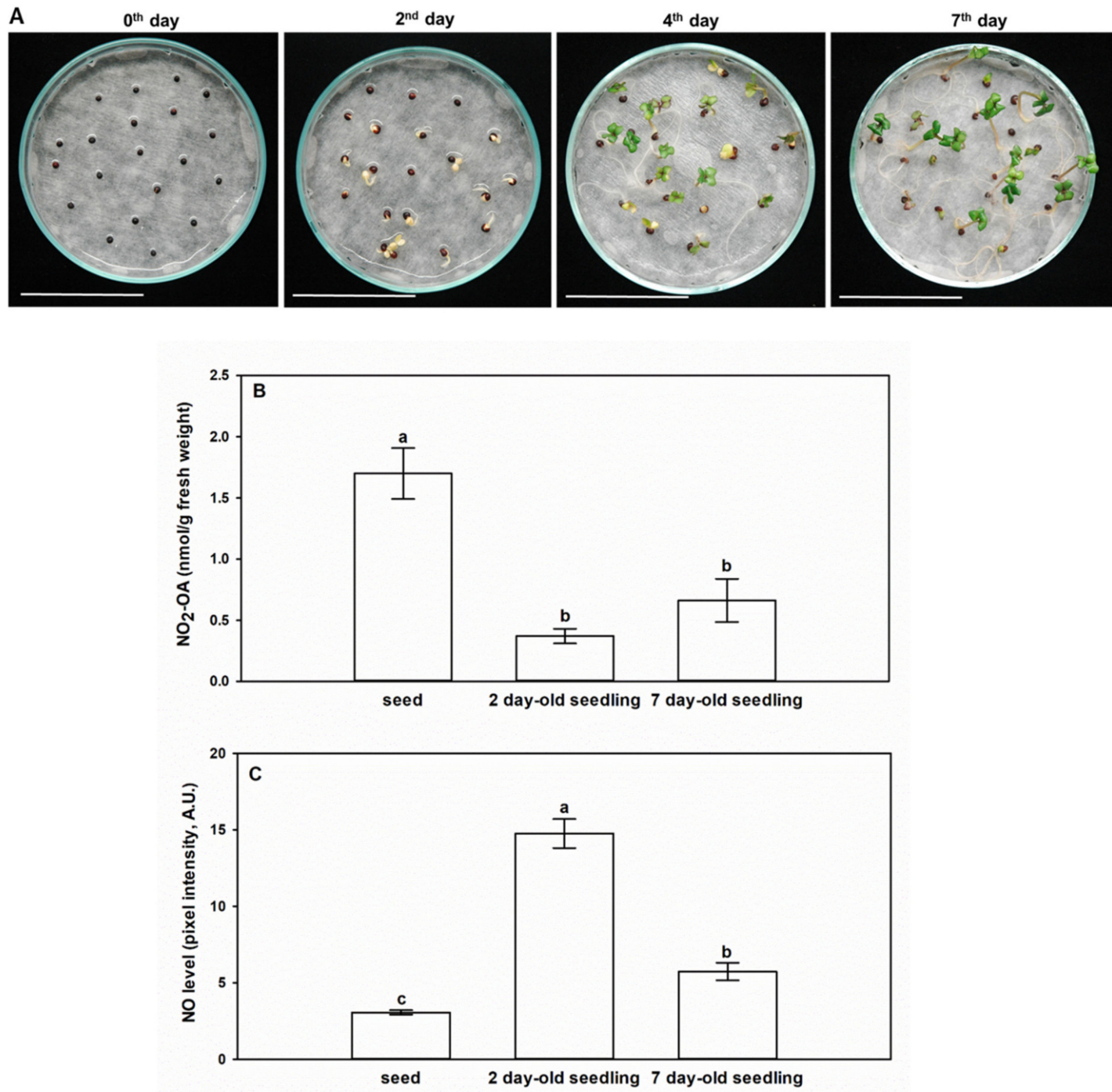

Figure 3. Levels of $\mathrm{NO}_{2}-\mathrm{OA}$ and $\bullet \mathrm{NO}$ change in opposite ways in the early stage of germination (day 0 ) and during seedling growth (2nd, 4 th and 7th days). (A) Representative photographs taken from Brassica napus seedlings on day 0 , and 2nd, 4th, and 7 th day after sowing. Bars $=4.5 \mathrm{~cm}$. (B) Mean concentrations of $\mathrm{NO}_{2}-\mathrm{OA}$ (nmol/g fresh weight, with standard errors) in seeds and differently developed seedlings of Brassica napus. (C) •NO levels (pixel intensity, arbitrary unit) in Brassica napus seeds, 2 day-old and 7 day-old seedlings. Different letters indicate significant differences according to the Holm-Sidak test $(\mathrm{P} \leq 0.001)$. 

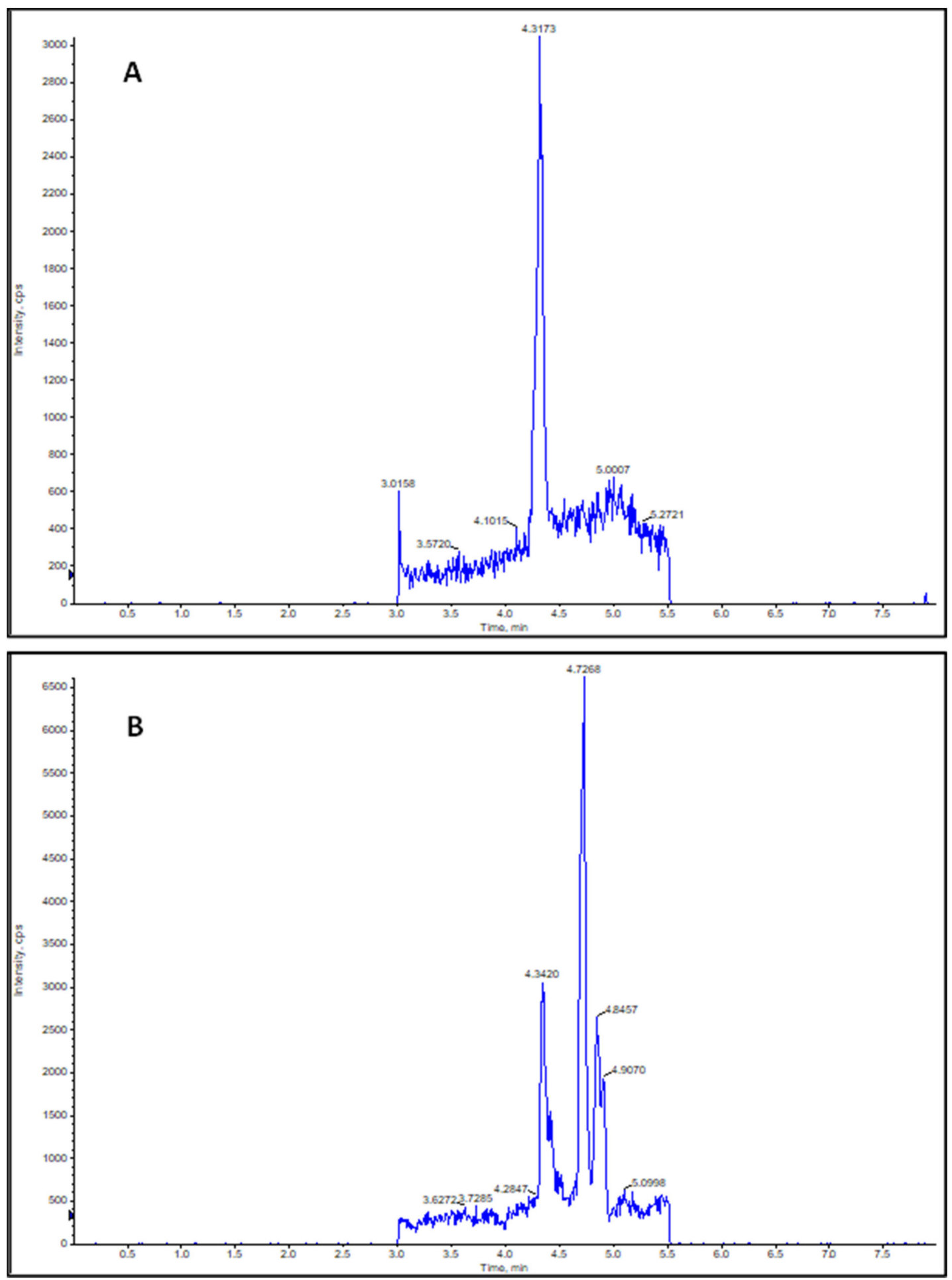

Figure 4. (A) Ion Chromatogram of $m / z 326.5$ of $\mathrm{NO}_{2}-\mathrm{OA}$ working solution (100 ng/mL). Peak retention time $(\mathrm{RT})=4.3173 \mathrm{~min}$. (B) Ion Chromatogram of $\mathrm{m} / \mathrm{z} 326.5$ of a sample derived from 7 - day- old Brassica napus seedlings. Peak retention time (RT) $=4.3420 \mathrm{~min}$.

Brassica napus seeds contained a notably high amount of $\mathrm{NO}_{2}$-OA compared to seedlings (Table 1 , Figure 3B). During the early phase of seedling growth (2nd day), the high $\mathrm{NO}_{2}-\mathrm{OA}$ content of Brassica seeds decreased by $78 \%$, and it continued to decline in the following two days (4th day). At the 7th day of seedling growth, the seedlings showed an increased $\mathrm{NO}_{2}$-OA content compared to the 
2- and 4-day-old seedlings, but it was only approximately $40 \%$ of the $\mathrm{NO}_{2}$-OA content of the seed. Separated analysis of the shoot and root material indicated that both organs of 7-day-old Brassica napus seedlings contained $\mathrm{NO}_{2}-\mathrm{OA}$ in similar quantities (Table 1). In Arabidopsis tissues, $\mathrm{NO}_{2}-\mathrm{OA}$ could not be detected, but $\mathrm{NO}_{2}$-Ln content was 2.9-fold higher in the seeds than in the 14-day-old seedlings ([6], Table 2). The relatively high $\mathrm{NO}_{2}-\mathrm{Ln}$ and $\mathrm{NO}_{2}-\mathrm{OA}$ contents of Arabidopsis and Brassica seeds (Table 1, Table 2) indicate the involvement of $\mathrm{NO}_{2}$-FA in seed germination possibly as endogenous $\bullet \mathrm{NO}$ donors [16]. To examine this hypothesis, we detected $\bullet N O$ levels in Brassica seeds and seedlings (2nd, 7 th days) (Figure 3C). Compared to seeds, on the 2 nd day the $\bullet$ NO content increased by almost 5 -fold. The opposite changes in $\mathrm{NO}_{2}-\mathrm{OA}$ and $\bullet \mathrm{NO}$ levels suggest that following the induction of germination $\mathrm{NO}_{2}-\mathrm{OA}$ as endogenous donor in the seed may release $\mathrm{NO}$ resulting in the decrease in its own free level and concomitant $\bullet \mathrm{NO}$ accumulation. Furthermore, it is important to note, that the measured $\mathrm{NO}_{2}-\mathrm{OA}$ concentrations in Brassica tissues are in the nanomolar range (Table 1, Figure 3B), that is an order of magnitude higher than the picomolar $\mathrm{NO}_{2}$-Ln concentrations of Arabidopsis seedlings, cell suspension, pea roots, leaves and rice leaves ([6,7], Table 2). In case of $\mathrm{NO}_{2}-\mathrm{OA}$ supplemented tomato cell suspension, the endogenous $\mathrm{NO}_{2}-\mathrm{OA}$ content was similar to that of the untreated Brassica napus seeds and seedlings ([8,9], Table 2). From the above comparisons, it can be concluded that the oleic acid content of Brassica napus seeds and seedlings is susceptible to physiological nitration making the plant a rich source of $\mathrm{NO}_{2}-\mathrm{OA}$.

Table 2. Concentration values of free $\mathrm{NO}_{2}$-FA determined in different plant species and experimental systems (modified from Ref. [7]). Abbreviations: ACSC = Arabidopsis cell suspension culture.

\begin{tabular}{|c|c|c|c|c|}
\hline Plant Species & $\begin{array}{c}\text { Organ or } \\
\text { Xperimental System }\end{array}$ & $\begin{array}{c}\text { Type of } \mathrm{NO}_{2}-\mathrm{FA} \\
\text { Detected }\end{array}$ & $\begin{array}{l}\text { Concentration of } \\
\mathrm{NO}_{2} \text { - FA Detected } \\
\text { (pmol/g Fresh } \\
\text { Weight) }\end{array}$ & Refs. \\
\hline \multirow{5}{*}{$\begin{array}{l}\text { Arabidopsis } \\
\text { thaliana }\end{array}$} & seed & $\mathrm{NO}_{2}-\mathrm{Ln}$ & 11.18 & \multirow{5}{*}{ [6] } \\
\hline & 14-day-old seedling & $\mathrm{NO}_{2}$ - $\mathrm{Ln}$ & 3.84 & \\
\hline & 30-day-old leaves & $\mathrm{NO}_{2}$-Ln & 0.36 & \\
\hline & 45 day-old leaves & $\mathrm{NO}_{2}$ - $\mathrm{Ln}$ & 0.54 & \\
\hline & 9-day-old ACSC & $\mathrm{NO}_{2}$-Ln & 0.28 & \\
\hline \multirow{4}{*}{ Pisum sativum } & root & $\mathrm{NO}_{2}$-Ln & 0.072 & \multirow{5}{*}{ [7] } \\
\hline & leaf & $\mathrm{NO}_{2}-\mathrm{Ln}$ & 0.084 & \\
\hline & mitochondria & $\mathrm{NO}_{2}-\mathrm{Ln}$ & & \\
\hline & peroxisomes & $\mathrm{NO}_{2}$-Ln & 0.282 & \\
\hline Oryza sativa & leaf & $\mathrm{NO}_{2}$-Ln & 0.748 & \\
\hline $\begin{array}{c}\text { Solanum } \\
\text { lycopersicum }\end{array}$ & $\begin{array}{l}\text { cell suspension treated with } \\
\mathrm{NO}_{2}-\mathrm{OA}(0.5,5,10,12.5,25 \text {, } \\
50 \mu \mathrm{M}, 1 \mathrm{~h} \text { or } 6 \mathrm{~h})\end{array}$ & $\mathrm{NO}_{2}-\mathrm{OA}$ & $\sim 2500$ & $\begin{array}{l}{[8]} \\
{[9]}\end{array}$ \\
\hline
\end{tabular}

2.4. Exogenous $\mathrm{NO}_{2}-\mathrm{OA}$ Treatment of Brassica Seeds Positively Influences $\bullet N O$ Levels and Germination Capacity

The 24-hour-long treatment with $100 \mu \mathrm{M} \mathrm{NO}$-OA caused 10-fold increment in the endogenous - NO level of seeds (Figure $5 \mathrm{~A}, \mathrm{~B}$ ), while $\mathrm{NO}_{2}-\mathrm{OA}$ at $50 \mu \mathrm{M}$ or $500 \mu \mathrm{M}$ concentrations did not cause significant changes in $\bullet$ NO levels compared to controls (50 or $500 \mu \mathrm{M}$ DMSO, respectively). The significant effect of $100 \mu \mathrm{M} \mathrm{NO}_{2}$-OA on $\bullet \mathrm{NO}$ level prevailed also on the 2 nd day after sowing, since the $\bullet \mathrm{NO}$ level of $\mathrm{NO}_{2}$-OA-supplemented seedlings was 4.7 times that of the control $(100 \mu \mathrm{M}$ DMSO, Figure $5 \mathrm{~A}, \mathrm{~B})$. The $\mathrm{NO}_{2}-\mathrm{OA}$-induced DAF-FM fluorescence was quenched by the $\bullet \mathrm{NO}$ scavenger cPTIO (Figure 5B) indicating that the alterations in DAF fluorescence correspond to $\bullet \mathrm{NO}$ level changes. Oleic acid (OA) treatments applied as controls did not influence $\bullet$ NO levels either in seeds or in 2 -day-old seedlings (Figure 5A). 

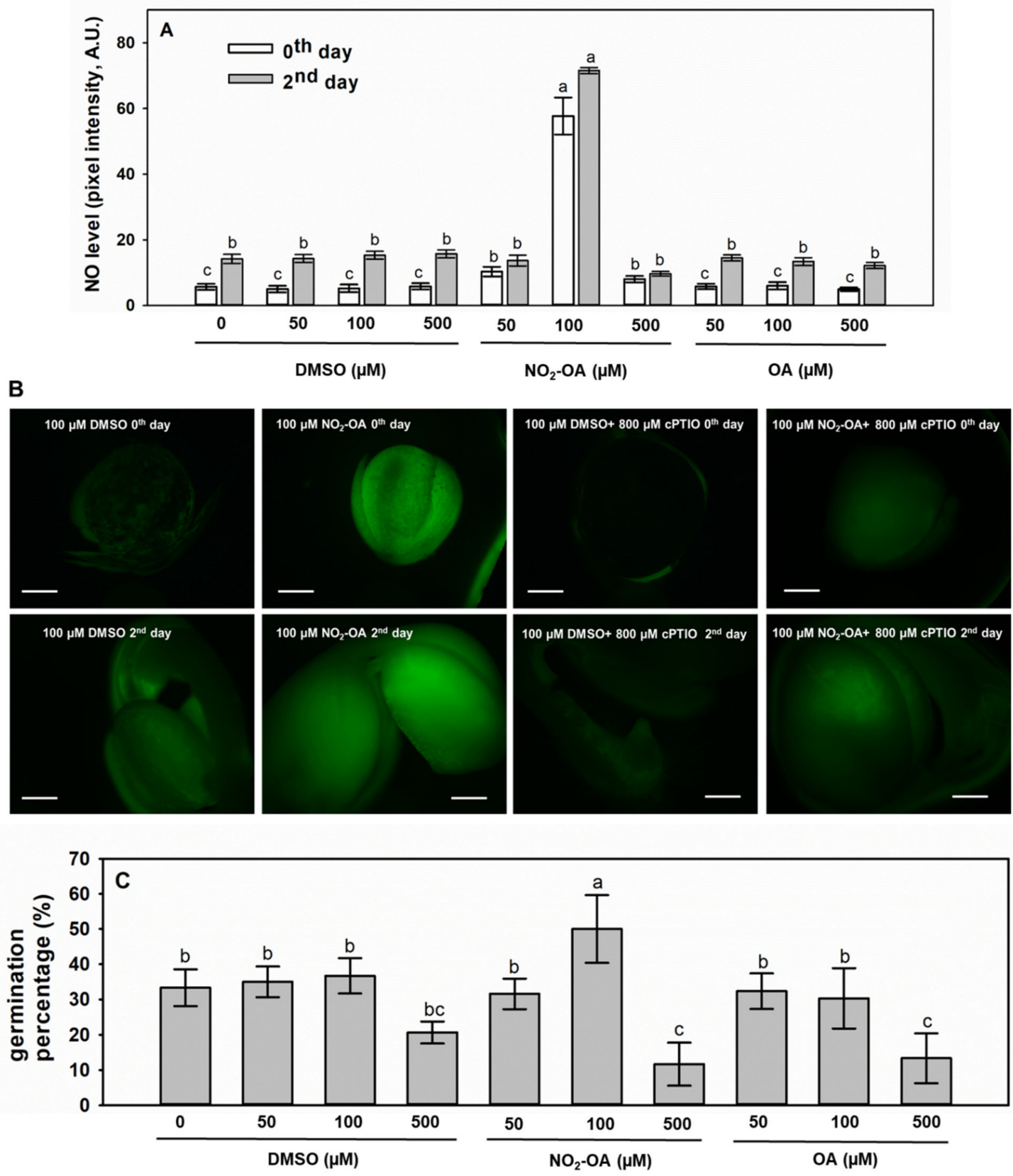

Figure 5. Exogenous $\mathrm{NO}_{2}-\mathrm{OA}$ increases endogenous $\bullet \mathrm{NO}$ levels and triggers germination of Brassica napus seeds. (A) Nitric oxide level in seeds (day 0 of germination) and seedlings (2nd day after sowing) of Brassica napus treated for $24 \mathrm{~h}$ with 50, 100 or $500 \mu \mathrm{M} \mathrm{NO}_{2}-\mathrm{OA}$ or with equal concentrations of OA. As controls, seeds were treated with $0,50,100$ or $500 \mu \mathrm{M}$ DMSO. Different letters indicate significant differences according to Holm-Sidak test $(\mathrm{P} \leq 0.001)$. (B) Representative fluorescent microscopic images of DAF FM-stained Brassica seeds and seedlings treated with $100 \mu \mathrm{M} \mathrm{NO}_{2}-\mathrm{OA}$ or $100 \mu \mathrm{M}$ DMSO for $24 \mathrm{~h}$ in the presence or absence of $800 \mu \mathrm{M}$ cPTIO. Bars $=800 \mu \mathrm{m}$. (C) Germination percentage (determined at the 2nd day after sowing) of Brassica seeds treated with 50, 100, or $500 \mu \mathrm{M}$ $\mathrm{NO}_{2}$-OA or with equal concentrations of OA. As controls, seeds were treated with $0,50,100$, or $500 \mu \mathrm{M}$ DMSO. Different letters indicate significant differences according to the Holm-Sidak test $(\mathrm{P} \leq 0.001)$.

The germination percentages were altered in accordance with $\bullet \mathrm{NO}$ levels, since $100 \mu \mathrm{M} \mathrm{NO}_{2}-\mathrm{OA}$ treatment doubled the percentage of germinated seeds compared to control (100 $\mu \mathrm{M}$ DMSO) (Figure 5C). DMSO alone at $50 \mu \mathrm{M}$ or $100 \mu \mathrm{M}$ concentrations had no effect on seed germination, although in the presence of $500 \mu \mathrm{M}$ DMSO germination percentage of Brassica seeds slightly decreased compared to control $(0 \mu \mathrm{M}$ 
DMSO). Moreover, OA at 50 or $100 \mu \mathrm{M}$ concentration exerted no effect on germination of $B$. napus seeds (Figure 5C). The effect of DMSO could dominate in case of $500 \mu \mathrm{M} \mathrm{NO}_{2}-\mathrm{OA}$ or $500 \mu \mathrm{M}$ OA treatments, since in these seeds the germination ability was weaker than in control and $\bullet \mathrm{NO}$ levels remained at control level (Figure 5A). These data clearly indicate that exogenous $\mathrm{NO}_{2}-\mathrm{OA}$ can result in the long-term increase of endogenous $\bullet$ NO level in Brassica napus seeds and seedlings, i.e., it may act as a $\bullet$ NO donor. The fact that nitro-fatty acids may act as $\bullet$ NO donors in plants has been previously raised [16]. It was revealed that $\mathrm{NO}_{2}$-Ln has the ability to release in vivo, in leaves and roots of old Arabidopsis plants [26], in Arabidopsis seedlings [16], and in Arabidopsis cell-suspension cultures [27]. Contrary to $\mathrm{NO}_{2}$-Ln and to $\mathrm{NO}_{2}-\mathrm{OA}$ in our study, exogenous application of $\mathrm{NO}_{2}-\mathrm{OA}(0.5,5,10,12.5,25$, or $50 \mu \mathrm{M}, 1 \mathrm{~h}$ or $6 \mathrm{~h})$ did not increase -NO level in tomato cell suspension as was recently reported by Di Palma et al. [8,9]. Contradiction of the results can be explained by that here higher concentration of $\mathrm{NO}_{2}-\mathrm{OA}(100 \mu \mathrm{M})$ were applied for longer time period $(24 \mathrm{~h})$ than in the studies of Di Palma et al. [8,9].

\section{5. $\mathrm{NO}_{2}-\mathrm{OA}$ Releases $\bullet \mathrm{NO}$ in Vitro}

Additionally, the $\bullet \mathrm{NO}$ donor nature of $\mathrm{NO}_{2}$ - $\mathrm{Ln}$ was proved by using several different in vitro approaches (DAF fluorescence, oxyhaemoglobin method, ozone chemiluminescence, [27]. In this work, we performed in vitro tests to support the hypothesis regarding the $\bullet \mathrm{NO}$ donor role of $\mathrm{NO}_{2}-\mathrm{OA}$ (Figure 6). Spectrofluorometric measurement of DAF-FM-associated fluorescence revealed that the sample containing $10 \mu \mathrm{M} \mathrm{NO}$-OA liberated a relatively small amount of $\bullet \mathrm{NO}$ during the $80 \mathrm{~min}$ period, while the same dosage of OA did not induce $\bullet \mathrm{NO}$ level increase compared to the blind sample containing only buffer and the fluorophore (Figure $6 \mathrm{~A}$ ). Moreover, $\mathrm{NO}_{2}-\mathrm{OA}$ liberated $\bullet \mathrm{NO}$ in a concentration-dependent manner and the fluorescence increase could be quenched by cPTIO. Elevating doses of OA did not increase $\bullet$ NO levels (Figure 6B).

Using the more sensitive $\bullet \mathrm{NO}$ electrode, we could quantify $\bullet \mathrm{NO}$ liberation in $\mathrm{NO}_{2}-\mathrm{OA}$ solution ( $\mathrm{pH} 5.8)$ within 5 min reaching its maximum $(\sim 30 \mathrm{nM} \bullet \mathrm{NO})$ after $20 \mathrm{~min}$ incubation. The produced $\bullet \mathrm{NO}$ concentrations (20-30 nM) quantified by ISO-NOP electrode in this study are similar to those measured by $\bullet \mathrm{NO}$ autoanalyzer in the case of $100 \mu \mathrm{M} \mathrm{NO}_{2}$-Ln or $80 \mu \mathrm{M} \mathrm{NO}_{2}$-LA [27]. The same concentration of OA showed no relevant $\bullet \mathrm{NO}$ releasing capacity in the solution (Figure $6 \mathrm{C}$ ). These in vitro data support the $\bullet \mathrm{NO}$ donor character of $\mathrm{NO}_{2}-\mathrm{OA}$ in solutions and the degree of $\bullet \mathrm{NO}$ liberation is similar to other $\mathrm{NO}_{2}$-FAs. However, the same dosage of S-nitrosoglutathione (GSNO) or sodium nitroprusside (SNP) produced approx. 10-fold higher $\bullet \mathrm{NO}$ concentration in solutions following 20 min incubation in light (data not shown) indicating that $\mathrm{NO}_{2}$-FAs (including $\mathrm{NO}_{2}-\mathrm{OA}$ ) $\bullet \mathrm{NO}$ donor capacity is much lower compared to "classical $\bullet \mathrm{NO}$ donors".

In our experimental system, $\mathrm{NO}_{2}$-OA $(100 \mu \mathrm{M}, 24 \mathrm{~h})$ treatment of Brassica seeds also promoted germination, presumably through the induction of high $\bullet \mathrm{NO}$ levels. In vitro tests revealed that the concentration of liberated $\bullet \mathrm{NO}$ is relatively low (Figure 6), but in seeds $\mathrm{NO}_{2}-\mathrm{OA}$ treatment caused intense $\bullet$ NO formation (Figure 5). Therefore, we assume that beyond direct $\bullet N O$ emission, secondary signal processes may also be activated in the presence of $\mathrm{NO}_{2}-\mathrm{OA}$ leading to the activation of $\bullet \mathrm{NO}$ metabolic routes in seeds and seedlings. It is well known, that $\bullet \mathrm{NO}$ attenuates seed dormancy and promotes germination and we are beginning to recognize also the molecular mechanisms of $\bullet$ NO action [28]. 

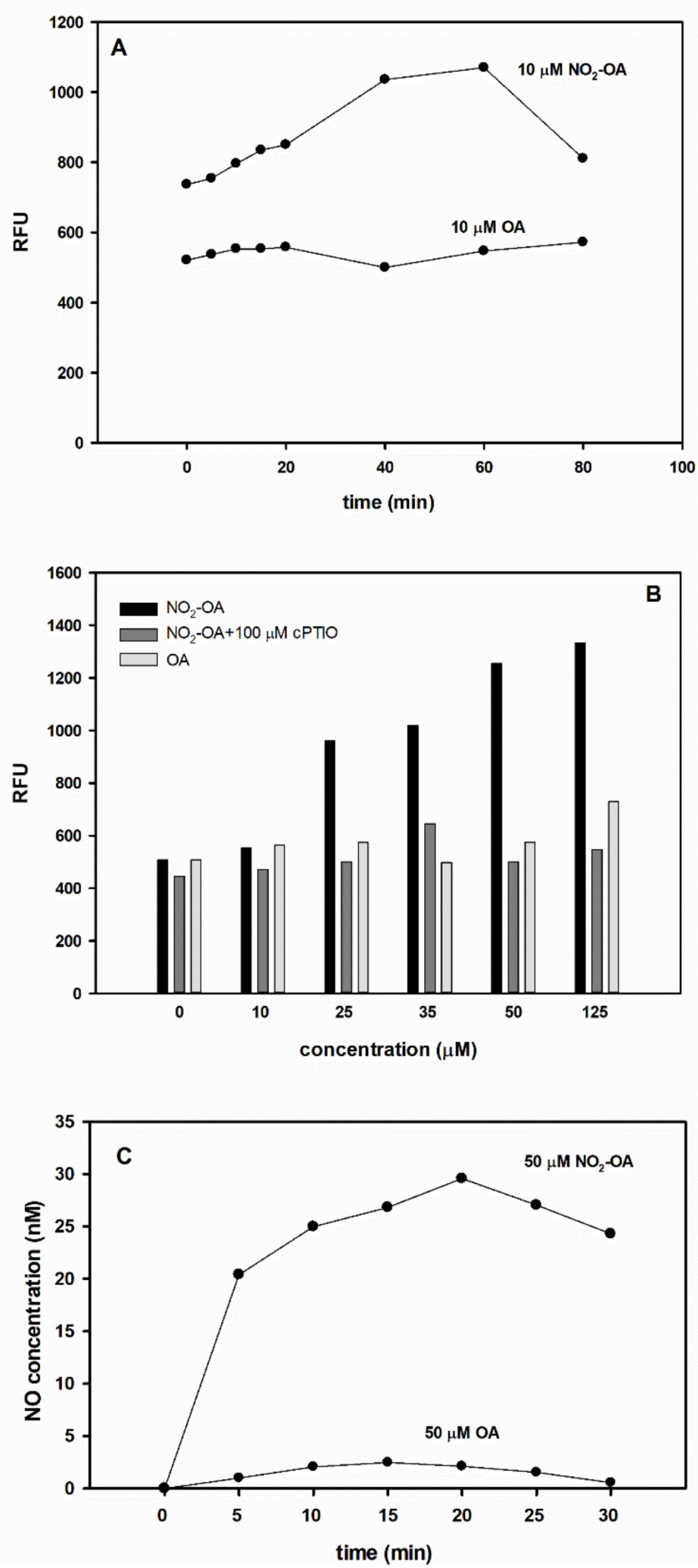

Figure 6. $\mathrm{NO}_{2}$-OA liberates $\bullet \mathrm{NO}$ in solutions (A) Relative fluorescence units (RFU) of DAF-FM fluorescence in solutions in the presence of $10 \mu \mathrm{M} \mathrm{NO}_{2}$-OA or $10 \mu \mathrm{M}$ OA measured at different time points. (B) Relative fluorescence units (RFU) of DAF-FM fluorescence in solutions containing different concentrations of $\mathrm{NO}_{2}-\mathrm{OA}$ (with or without $100 \mu \mathrm{M}$ cPTIO) or OA. Data were recorded after 20 min incubation. (C) $\bullet N O$ concentration (nM) measured by ISO-NOP ( $2 \mathrm{~mm}$ ) electrode in solutions containing $50 \mu \mathrm{M} \mathrm{NO}_{2}$-OA or OA measured at different time points. 


\section{Materials and Methods}

\subsection{Plant Material and Growing Conditions}

Experiments were carried out on Brassica napus L. (cv. GK Gabriella) seedlings. The seeds were obtained from the Cereal Research Non-profit Ltd., Szeged, Hungary. Brassica seeds were surface sterilised in $70 \%(\mathrm{v} / \mathrm{v})$ ethanol and $5 \%(\mathrm{v} / \mathrm{v})$ sodium hypochlorite, then placed on moistened filter paper in Petri dishes (9 cm diameter, 30 seeds/Petri dish). Germination took place under controlled conditions ( $150 \mu \mathrm{mol} \mathrm{m}{ }^{-2} \mathrm{~s}^{-1}$ photon flux density, $12 \mathrm{~h} / 12 \mathrm{~h}$ light/dark cycle, relative humidity 55-60\% and temperature $25 \pm 2{ }^{\circ} \mathrm{C}$ ). For the $\mathrm{NO}_{2}-\mathrm{OA}$ analysis, the samples were taken at the $2 \mathrm{nd}, 4$ th and $7 \mathrm{th}$ day after sowing. Additionally, seeds after imbibition, at the early stage of germination (day 0 ) were also sampled for $\mathrm{NO}_{2}-\mathrm{OA}$ quantification. Plant material ( $5 \mathrm{~g}$ ) was collected, frozen in liquid nitrogen and stored at $-80^{\circ} \mathrm{C}$ until the analyses.

\subsection{Synthesis and Structure Determination of 9-Nitro-Oleic Acid Standard}

Using the slightly modified method of Woodcock et al. [29], 9-nitro-oleic acid was synthesized. Bromononanoic acid was used as starting material for allylization to gain 9-bromononanoic acid allyl ester. This compound was nitrated using silver nitrite. In the next step, 10-hydroxy-9-nitro-octadecanoic acid allyl ester was synthesized by the addition of nonyl aldehyde and 1,8-diazabicyclo[5.4.0]undec-7-ene. This compound was acylated with acetic anhydride in the presence of $p$-toluenesulfonic acid to gain 10-acetoxy-9-nitro-octadecanoic acid allyl ester. Deacylation in the presence of $\mathrm{Na}_{2} \mathrm{CO}_{3}$ led to the synthesis of 9-nitro-oleic acid allyl ester. The final product 9-nitro-oleic acid was gained by a catalytic hydrolysis using palladium tetrakis(triphenylphosphine). Purification was carried out by flash chromatography on silica gel (Merck, 40-63 $\mu \mathrm{m}$ ) using a gradient of 0.5\% acetic acid. Fractions with similar compositions were combined and the combined fraction containing a spot with remarkable absorption at $254 \mathrm{~nm}$ and with an $\mathrm{R}_{\mathrm{f}}$ approximately 0.5 (silica gel plate, eluent $\mathrm{CHCl}_{3}-\mathrm{MeOH}$ 95:5) was subjected to NMR identification and purity check.

${ }^{1} \mathrm{H}(500.1 \mathrm{MHz})$ and ${ }^{13} \mathrm{C}(125.6 \mathrm{MHz}) \mathrm{NMR}$ spectra were recorded in $\mathrm{CDCl}_{3}$ on a Bruker Avance DRX-500 spectrometer. The peaks of the residual solvent were taken as reference points. The compound was identified by comparison of its chemical shifts with literature data [25,30]. Mass spectrometric identification was performed on an API 2000 triple quadrupole tandem mass spectrometer (MDS Sciex, Toronto, ON, Canada) equipped with electrospray ion source. Mass spectrometric measurement was carried out by direct infusion in Q1 MS scan type in negative mode. Flow rate was set to $40 \mu \mathrm{L} / \mathrm{min}$, scan range was set from $\mathrm{m} / \mathrm{z} 100$ to 1000 , ion source temperature was set to $100{ }^{\circ} \mathrm{C}$. The nebulizer gas was set to 18 psi. Measured molecule ion mass shown to be $m / z 326.5$, calculated neutral molecule mass was 327.4589 Da.

\subsection{LC-MS Quantification of $\mathrm{NO}_{2}-\mathrm{OA}$ in Brassica Seeds and Seedlings}

For the quantification of $\mathrm{NO}_{2}-\mathrm{OA}, 5 \mathrm{~g}$ of fresh plant material (seeds, whole seedlings or separated root and shoot) was used and the analysis was conducted by LC-MS. Mass spectrometry measurement was performed using single ion monitoring (SIM) on an API 2000 triple quadrupole tandem mass spectrometer (MDS Sciex, Toronto, ON, Canada) equipped with electrospray ion source. The nebulizer and heater gas was nitrogen, generated from a Peak NM20Z nitrogen generator (Peak Scientific Instruments Ltd., Scotland, UK) coupled with an Atlas Copco SF 4FF compressor. The nebulizer gas was set to $30 \mathrm{psi}$, the heater gas was set to 80 psi. The ion source temperature was set to $300{ }^{\circ} \mathrm{C}$. Measurement was in negative mode. The voltage volumes were adjusted to $\mathrm{m} / \mathrm{z} 326.5$, the collision energy was set to $-5 \mathrm{~V}$, focusing potential to $-330 \mathrm{~V}$, declustering potential to $-61 \mathrm{~V}$ and entrance potential to $-10 \mathrm{~V}$. HPLC separation was performed with Shimadzu HPLC system (Kyoto, Kyoto Prefecture, Japan): DGU-20A3 degasser, CBM-20A controller, two LC-20AD pumps, SIL-20A HT autosampler, CTO-20AC column thermostat, SPD-20A UV-Vis detector, using Kinetex F5 $(100 \times 4.6 \mathrm{~mm}$, $2.6 \mu \mathrm{m}, 100 \mathrm{~A})$ (Phenomenex, Inc., Torrance, CA, USA). Elution was carried out with the gradient 
system of $\mathrm{H}_{2} \mathrm{O}$-methanol ( 0 min: $\mathrm{H}_{2} \mathrm{O}$-methanol 2:8, $0.6 \mathrm{~min}: 2: 8,1.5 \mathrm{~min}:$ 0:1, 3 min: 0:1, 3.2 min: 2:8, $8.2 \mathrm{~min}: 2: 8)$. The oven was set to $40^{\circ} \mathrm{C}$ and the flow rate was $600 \mu \mathrm{L} / \mathrm{min}$. The retention time of $\mathrm{NO}_{2}-\mathrm{OA}$ was $4.32 \mathrm{~min}$. Data acquisition was performed with Analyst software (ver. 1.6.3). Quantification of nitro-oleic acid was carried out by using the synthesized standard (see in Section 2.2).

Plant material was extracted with pure $\mathrm{MeOH}$ (HPLC grade) in a VWR Ultrasonic Cleaner USC 300D (capacity: $1 \mathrm{~L}$, internal dimension: $\mathrm{W} \times \mathrm{D} \times \mathrm{H} 240 \times 135 \times 100 \mathrm{~mm}$ ) ultrasonic bath for $10 \mathrm{~min}$, with dual half-wave sound with sweep, frequency was set to $45 \mathrm{kHz}$, ultrasonic power to $80 \mathrm{~W}$, temperature was set to $25^{\circ} \mathrm{C}$, and filtered through a syringe filter (PTFE, $0.45 \mu \mathrm{m}$ pore size, Labex Ltd.), the first half $\mathrm{ml}$ of the filtrate was thrown into the waste. From each plant part, three parallel samples were prepared, and each sample was injected three times.

\section{4. $\bullet$ NO Detection in Brassica napus Seeds and Seedlings}

Nitric oxide levels were examined in seeds as well as in 2- and 7-day-old seedlings of Brassica napus using the 4-amino-5-methylamino- $2^{\prime}, 7^{\prime}$-difluorofluorescein diacetate (DAF-FM DA) according to Kolbert et al. [31]. Plant samples were incubated in $10 \mu \mathrm{M}$ dye solution for $30 \mathrm{~min}$ (darkness, $25 \pm 2{ }^{\circ} \mathrm{C}$ ) and washed twice with Tris- $\mathrm{HCl}(10 \mathrm{mM}, \mathrm{pH}$ 7.4). Microscopic analysis was accomplished under Zeiss Axiovert $200 \mathrm{M}$ inverted microscope (Carl Zeiss, Jena, Germany) equipped with a high-resolution digital camera (AxiocamHR, HQ CCD, Carl Zeiss, Jena, Germany) and filter set 10 (exc.: 450-490, em.: 515-565 nm). Pixel intensities were measured on digital photographs (at least 10 photographs per sample per experiment) using Axiovision Rel. 4.8 software (Carl Zeiss, Jena, Germany).

\section{5. $\mathrm{NO}_{2}-\mathrm{OA}$ Treatment of Brassica napus Seeds}

The synthesized $\mathrm{NO}_{2}-\mathrm{OA}$ or OA was dissolved in dimethyl sulfoxide (DMSO) in order to obtain a stock solution $(10 \mathrm{mM})$. The $\mathrm{NO}_{2}-\mathrm{OA}$ or $\mathrm{OA}$ stock was diluted with distilled water to the final concentrations (50, $100,500 \mu \mathrm{M})$. Control solutions were prepared by measuring the volume of DMSO corresponding to the stock solutions (indicated as 0, 50, 100, or 500 DMSO). Brassica napus seeds (30 seeds per treatment) were incubated in $\mathrm{NO}_{2}-\mathrm{OA}$, in OA or in control solutions for $24 \mathrm{~h}$ on an orbital shaker and then were placed on moist filter paper in Petri dishes (20 seeds/Petri dish). Sets of seeds were treated with $\mathrm{NO}_{2}-\mathrm{OA}$ or control solutions in the presence of $800 \mu \mathrm{M}$ 2-(4-carboxyphenyl)-4,4,5,5-tetramethylimidazoline-1-oxyl-3-oxide (cPTIO). Germination took place as indicated above. Nitric oxide levels were detected in seeds prior to germination (day 0), and in seedlings 2 days after sowing (2nd day). Germination percentages (\%) were also calculated.

\subsection{Spectrofluorometric Determination of $\bullet N O$ Levels}

- NO liberation from $\mathrm{NO}_{2}$-OA solutions were detected by fluorescence spectrophotometry (Ref. [27] with modifications). Reaction mixtures ( $2 \mathrm{~mL}$ final volume) containing 0 (blind) 10, 25, 35, 50, $125 \mu \mathrm{M} \mathrm{NO} \mathrm{N}_{2}$-OA or the same concentrations of OA, plus $2 \mu \mathrm{M}$ DAF-FM and Tris- $\mathrm{HCl}(\mathrm{pH} 7.4)$ buffer were incubated at room temperature in the dark for several time periods (5-80 min) and the emitted fluorescence was recorded by a spectrofluorimeter (Hitachi F-4500, Hitachi Ltd., Tokyo, Japan). Excitation wavelength was set at $485 \mathrm{~nm}$ and emissions were measured at $515 \mathrm{~nm}$. The $\mathrm{NO}_{2}-\mathrm{OA}$-induced fluorescence was quenched by the addition of $100 \mu \mathrm{M}$ cPTIO.

\subsection{Measurement of $\bullet N O$ Concentration by $\bullet N O$-Specific Electrode}

The $\bullet N O$-sensitive electrode (ISO-NOP, 2 mm, World Precision Instruments Inc., Sarasota, FL, USA) was calibrated using a method based on S-nitroso-N-acetylpenicillamine (SNAP) decomposition to $\bullet \mathrm{NO}$ in the presence of copper [32]. Two $\mathrm{mL}$ of $\mathrm{NO}_{2}-\mathrm{OA}$ or OA (both at $50 \mu \mathrm{M}$ concentration) solutions were prepared in a 5-mL glass bottle and were measured immediately after preparation. To ensure constant mixing of the solution a magnetic stirrer was applied during the measurement. $\bullet$ NO concentration $(\mathrm{nM})$ was calculated from a standard curve. 


\subsection{Statistical Analysis}

All results are shown as mean \pm SE. Data were statistically evaluated by the Holm-Sidak method (One-way ANOVA, P $\leq$ 0.001) using SigmaPlot 12.

\section{Conclusions}

Following successful standard synthesis and method optimization, we have been the first to observe that Brassica seeds and seedlings contain free $\mathrm{NO}_{2}$-OA. Exogenous treatment of Brassica seeds with $\mathrm{NO}_{2}$-OA promoted germination and increased endogenous $\bullet \mathrm{NO}$ level suggesting that $\mathrm{NO}_{2}-\mathrm{OA}$ may be involved in germination as an $\bullet \mathrm{NO}$ donor. The $\bullet \mathrm{NO}$ liberating capacity of $\mathrm{NO}_{2}-\mathrm{OA}$ was proved also by in vitro approaches (spectrofluorometric detection of DAF-FM fluorescence and $\bullet \mathrm{NO}$-sensitive electrode). Due to their relatively high $\mathrm{NO}_{2}$-OA concentrations, Brassica sprouts can be considered as a good source of dietary $\mathrm{NO}_{2}$-OA intake in addition to their nutrient, mineral and vitamin content. Therefore, future studies should quantify the $\mathrm{NO}_{2}$-OA content of additional Brassica species and food plants.

Supplementary Materials: The following are available online at http://www.mdpi.com/2223-7747/9/3/406/s1. Figure S1: Chromatograms of B. napus seeds or seedlings (A) Ion chromatogram of $\mathrm{m} / z 326.5$ of a sample derived from Brassica napus seed. (B) Ion chromatogram of $\mathrm{m} / \mathrm{z} 326.5$ of a sample derived from 2-day-old Brassica napus seedling. (C) Ion chromatogram of $\mathrm{m} / \mathrm{z} 326.5$ of a sample derived from 4-day-old Brassica napus seedling. (D) Ion chromatogram of $\mathrm{m} / \mathrm{z} 326.5$ of a sample derived from 7-day-old Brassica napus shoot. (E) Ion chromatogram of $\mathrm{m} / \mathrm{z}$ 326.5 of a sample derived from 7-day-old Brassica napus root.

Author Contributions: Conceptualization, D.C. and Z.K.; Investigation, M.V., G.F., D.O., A.H., Á.M., and N.K.; Writing_Original Draft Preparation, M.V., D.C., and Z.K.; Writing—Review and Editing, A.Ö., D.C., and Z.K. All authors have read and agreed to the published version of the manuscript.

Funding: This research was funded by the National Research, Development and Innovation Fund (Grant no. NKFI-6, K120383) and by the EU-funded Hungarian grant EFOP-3.6.1-16-2016-00008. Zs. K. was supported by the János Bolyai Research Scholarship of the Hungarian Academy of Sciences (Grant no. BO/00751/16/8) and by UNKP-18-4 New National Excellence Program of the Ministry of Human Capacities.

Acknowledgments: The Authors thank Éva Kapásné Török for her valuable assistance during the experiments.

Conflicts of Interest: The authors declare that there is no conflict of interest.

\section{References}

1. Melo, T.; Montero-Bullón, J.F.; Domingues, P.; Domingues, M.R. Discovery of bioactive nitrated lipids and nitro-lipid-protein adducts using mass spectrometry-based approaches. Redox Biol. 2019, 23, 101-106. [CrossRef]

2. Buchan, G.J.; Bonacci, G.; Fazzari, M.; Salvatore, S.R.; Gelhaus Wendell, S. Nitro-fatty acid formation and metabolism. Nitric Oxid. 2018, 79, 38-44. [CrossRef]

3. Pryor, W.A.; Lightsey, J.W.; Church, D.F. Reaction of nitrogen dioxide with alkenes and polyunsaturated fatty acids: Addition and hydrogen abstraction mechanisms. J. Am. Chem. Soc. 1982, 104, 6685-6692. [CrossRef]

4. d'Ischia, M.; Napolitano, A.; Manini, P.; Panzella, L. Secondary targets of nitrite-derived reactive nitrogen species: Nitrosation/nitration pathways, antioxidant defense mechanisms and toxicological implications. Chem. Res. Toxicol. 2011, 24, 2071-2092. [CrossRef]

5. Fazzari, M.; Trostchansky, A.; Schopfer, F.J.; Salvatore, S.R.; Sánchez-Calvo, B.; Vitturi, D.; Valderrama, R.; Barroso, J.B.; Radi, R.; Freeman, J.B.; et al. Olives and olive oil are sources of electrophilic fatty acid nitroalkenes. PLoS ONE 2014, 9, e84884. [CrossRef] [PubMed]

6. Mata-Pérez, C.; Sánchez-Calvo, B.; Padilla, M.N.; Begara-Morales, J.C.; Luque, F.; Melguizo, M.; Jiménez-Ruiz, J.; Fierro-Risco, J.; Peñas-Sanjuán, A.; Valderrama, R.; et al. Nitro-fatty acids in plant signaling: Nitro-linolenic acid induces the molecular chaperone network in Arabidopsis. Plant Physiol. 2016, 170, 686-701. [CrossRef] [PubMed]

7. Mata-Pérez, C.; Sánchez-Calvo, B.; Padilla, M.N.; Begara-Morales, J.C.; Valderrama, R.; Corpas, F.J.; Barroso, J.B. Nitro-fatty acids in plant signaling: New key mediators of nitric oxide metabolism. Redox Biol. 2017, 11, 554-561. [CrossRef] [PubMed] 
8. Di Palma, A.A.; Di Fino, L.M.; Salvatore, S.R.; D’Ambrosio, J.M.; Grozeff, G.E.G.; García-Mata, C.; Schopfer, F.J.; Laxalt, A.M. Nitro-oleic acid induced reactive oxygen species formation and plant defense signaling in tomato cell suspensions. BioRxiv 2018, in press. [CrossRef]

9. Di Palma, A.A.; Di Fino, L.M.; Salvatore, S.R.; D'Ambrosio, J.M.; García-Mata, C.; Schopfer, F.J.; Laxalt, A.M. Nitro-oleic acid triggers ROS production via NADPH oxidase activation in plants: A pharmacological approach. J. Plant Physiol. 2020, 246-247, 153128, in press. [CrossRef]

10. Rudolph, V.; Rudolph, T.K.; Schopfer, F.J.; Bonacci, G.; Woodcock, S.R.; Cole, M.P.; Baker, P.R.S.; Ramani, R.; Freeman, B.A. Endogenous generation and protective effects of nitro-fatty acids in a murine model of focal cardiac ischaemia and reperfusion. Cardiovasc. Res. 2010, 85, 155-166. [CrossRef] [PubMed]

11. Baker, L.M.; Baker, P.R.; Golin-Bisello, F.; Schopfer, F.J.; Fink, M.; Woodcock, S.R.; Branchaud, B.P.; Radi, R.; Freeman, B.A. Nitro-fatty acid reaction with glutathione and cysteine. Kinetic analysis of thiol alkylation by a Michael addition reaction. J. Biol. Chem. 2007, 282, 31085-31093. [CrossRef] [PubMed]

12. Aranda-Caño, L.; Sánchez-Calvo, B.; Begara-Morales, J.C.; Chaki, M.; Mata-Pérez, C.; Padilla, M.N.; Valderrama, R.; Barroso, J.B. Post-translational modification of proteins mediated by nitro-fatty acids in plants: Nitroalkylation. Plants 2019, 8, 82. [CrossRef]

13. Rubbo, H.; Parthasarathy, S.; Barnes, S.; Kirk, M.; Kalyanaraman, B.; Freeman, B.A. Nitric oxide inhibition of lipoxygenase-dependent liposome and low-density lipoprotein oxidation: Termination of radical chain propagation reactions and formation of nitrogen-containing oxidized lipid derivatives. Arch. Biochem. Biophys. 1995, 324, 15-25. [CrossRef] [PubMed]

14. Lima, É.S.; Bonini, M.G.; Augusto, O.; Barbeiro, H.V.; Souza, H.P.; Abdalla, D.S.P. Nitrated lipids decompose to nitric oxide and lipid radicals and cause vasorelaxation. Free Radic. Biol. Med. 2005, 39, 532-539. [CrossRef] [PubMed]

15. Schopfer, F.J.; Baker, P.R.S.; Giles, G.; Chumley, P.; Batthyany, C.; Crawford, J.; Patel, R.P.; Hogg, N.; Branchaud, B.P.; Lancaster, J.R.; et al. Fatty acid transduction of nitric oxide signaling: Nitrolinoleic acid is a hydrophobically stabilized nitric oxide donor. J. Biol. Chem. 2005, 280, 19289-19297. [CrossRef]

16. Mata-Pérez, C.; Sánchez-Calvo, B.; Begara-Morales, J.C.; Padilla, M.N.; Valderrama, R.; Corpas, F.J.; Barroso, J.B. Nitric oxide release from nitro-fatty acids in Arabidopsis roots. Plant Signal. Behav. 2016, 11, e1154255. [CrossRef]

17. Villacorta, L.; Zhang, J.; Garcia-Barrio, M.T.; Chen, X.; Freeman, B.A.; Chen, Y.E.; Cui, T. Nitro-linoleic acid inhibits vascular smooth muscle cell proliferation via the Keap1/Nrf2 signaling pathway. Am. J. Physiol. Heart Circ. Physiol. 2007, 293, 770-776. [CrossRef]

18. Nie, H.; Xue, X.; Li, J.; Liu, X.; Lv, S.; Guan, G.; Liu, H.; Liu, G.; Liu, S.; Chen, Z. Nitro-oleic acid attenuates ogd/r-triggered apoptosis in renal tubular cells via inhibition of Bax mitochondrial translocation in a PPAR- $\gamma$-dependent manner. Cell. Physiol. Biochem. 2015, 35, 1201-1218. [CrossRef]

19. Kansanen, E.; Kuosmanen, S.M.; Ruotsalainen, A.K.; Hynynen, H.; Levonen, A.L. Nitro-oleic acid regulates endothelin signaling in human endothelial cells. Mol. Pharmacol. 2017, 92, 481-490. [CrossRef]

20. Yang, R.X.; Fan, J.G. Nitro-oleic acid as a new drug candidate for non-alcoholic steatohepatitis. EBioMedicine 2019, 42, 32-33. [CrossRef]

21. Liu, H.; Jia, Z.; Soodvilai, S.; Guan, G.; Wang, M.H.; Dong, Z.; Symons, J.D.; Yang, T. Nitro-oleic acid protects the mouse kidney from ischemia and reperfusion injury. Am. J. Physiol. Renal Physiol. 2008, 295, 942-949. [CrossRef] [PubMed]

22. Rom, O.; Xu, G.; Guo, Y.; Zhu, Y.; Wang, H.; Zhang, J.; Fan, Y.; Liang, W.; Lu, H.; Liu, Y.; et al. Nitro-fatty acids protect against steatosis and fibrosis during development of nonalcoholic fatty liver disease in mice. EBioMedicine 2019, 41, 62-72. [CrossRef] [PubMed]

23. Márton, M.; Mándoki, Z.S.; Csapó-Kiss, Z.S.; Csapó, J. The role of sprouts in human nutrition. A review. Acta Univ. Sapientiae Aliment. 2010, 3, 81-117.

24. Sharafi, Y.; Majidi, M.M.; Goli, S.A.H.; Rashidi, F. Oil content and fatty acids composition in Brassica species. Int. J. Food Proper. 2015, 18, 2145-2154. [CrossRef]

25. Gorczynski, M.J.; Huang, J.; King, S.B. Regio- and stereospecific syntheses and nitric oxide donor properties of (E)-9- and (E)-10-nitrooctadec-9-enoic acids. Org. Lett. 2006, 8, 2305-2308. [CrossRef]

26. Sánchez-Calvo, B.; Barroso, J.B.; Corpas, F.J. Hypothesis: Nitro-fatty acids play a role in plant metabolism. Plant Sci. 2013, 199, 1-6. [CrossRef] 
27. Mata-Pérez, C.; Sánchez-Calvo, B.; Begara-Morales, J.C.; Carreras, A.; Padilla, M.N.; Melguizo, M.; Valderrama, R.; Corpas, F.J.; Barroso, J.B. Nitro-linoleic acid is a nitric oxide donor. Nitric Oxid. 2016, 57, 57-63. [CrossRef]

28. Signorelli, S.; Considine, M.J. Nitric oxide enables germination by a four-pronged attack on ABA-induced seed dormancy. Front. Plant Sci. 2018, 9, 296. [CrossRef]

29. Woodcock, S.R.; Bonacci, G.; Gelhaus, S.L.; Schopfer, F.J. Nitrated fatty acids: Synthesis and measurement. Free Radic. Biol. Med. 2013, 59, 14-26. [CrossRef]

30. Woodcock, S.R.; Marwitz, A.J.V.; Bruno, P.; Branchaud, B.P. Synthesis of nitrolipids. all four possible diastereomers of nitrooleic acids: (E)- and (Z)-, 9- and 10-nitro-octadec-9-enoic acids. Org. Lett. 2006, 8, 3931-3934. [CrossRef]

31. Kolbert, Z.S.; Pető, A.; Lehotai, N.; Feigl, G.; Ördög, A.; Erdei, L. In Vivo and In Vitro studies on fluorophore-specificity. Acta Biol. Szeged. 2012, 65, 37-41.

32. Zhang, $X$. Real time and In Vivo monitoring of nitric oxide by electrochemical sensors from dream to reality. Front. Biosci. 2004, 9, 3434-3446. [CrossRef] [PubMed]

(C) 2020 by the authors. Licensee MDPI, Basel, Switzerland. This article is an open access article distributed under the terms and conditions of the Creative Commons Attribution (CC BY) license (http://creativecommons.org/licenses/by/4.0/). 